Vol 13, Issue 11, 2020

\title{
EFFECT OF STERCULIA QUADRIFIDA R. BR BARK TO IN VITRO DPPH RADICAL AND GLUTATHIONE PEROXIDASE ON DIABETIC WISTAR RATS
}

\author{
RAMBU KONDA A PRAING, TITIK SUNARNI* \\ Pharmaceutical Biology Research Group, Faculty of Pharmacy, Setia Budi University, Indonesia. Email: titiksunarniusb1@gmail.com \\ Received: 10 June 2020, Revised and Accepted: 15 September 2020
}

ABSTRACT

Objective: The aims of the research were to evaluate the antioxidant effect of Sterculia quadrifida R.Br bark by in vitro 1,1-biphenyl-2-picryl-hydrazyl (DPPH) radical scavenging method and glutathione peroxidase (GPx) activity on diabetic Wistar rats model.

Methods: S. quadrifida bark powder was extracted in ethanol $70 \%$ by maceration method. The antioxidant activity of ethanol extract was tested by DPPH radical scavenging method. The activity of GPx was evaluated from the liver of alloxan-induced diabetic rats. The antioxidant activity was determined by measuring the absorbance using ultraviolet-visible spectrophotometry method.

Results: The ethanol extract of $S$. quadrifida bark had a strong DPPH radical scavenging activity, with the $\mathrm{IC}_{50}$ value was $4.86 \pm 0.01 \mathrm{ug} / \mathrm{ml}_{\text {, besides that }}$ the extract also showed significantly activity of GPx $(\mathrm{p}<0.05)$ at a dose of 65, 130, and $260 \mathrm{mg} / \mathrm{kg} \mathrm{bw}$.

Conclusion: The ethanol extract of S. quadrifida bark had a potent antioxidant activity by DPPH radical scavenging and GPx activity.

Keywords: Sterculia quadrifida R.Br, 1,1-biphenyl-2-picryl-hydrazyl, Glutathione peroxidase, Antioxidant.

(C) 2020 The Authors. Published by Innovare Academic Sciences Pvt Ltd. This is an open access article under the CC BY license (http://creativecommons. org/licenses/by/4. 0/) DOI: http://dx.doi.org/10.22159/ajpcr.2020.v13i11.38805

\section{INTRODUCTION}

The reactive oxygen species (ROS) are produced as by products during the metabolic processes. Normally, these ROS are produced in small amounts in the body for various physiological functions, but if they produced in excessive amounts, they could cause oxidative stress [1]. Oxidative stress is an important risk factor in the pathogenesis of numerous chronic diseases. These also effect various enzyme systems and cause damage which may further contribute to conditions such as cancer, ischemia, atherosclerosis, aging, rheumatoid arthritis, and neurological disorders [2].

Antioxidants can be broadly defined as any substance that delays or inhibits oxidative damage to a target molecule. The main characteristic of an antioxidant is its ability to neutralize free radical [3]. The antioxidant components of natural origin have attracted special interest because they can protect human body from free radicals. Antioxidants such as polyphenols, ascorbic acid, Vitamin A, alpha-lipoic acid, thioredoxin, glutathione, melatonin, coenzyme $\mathrm{Q}$ beta-carotenoids, alpha-tocopherols, as well as antioxidant enzymes [4].Enzymatic antioxidantsinclude primary enzymes such as superoxide dismutase, catalase, glutathione peroxidase (GPx), and secondary enzymes include glutathione reductase [5]. These enzymes have been widely investigated for the prevention and treatment of diseases resulting from oxidative damage.

Sterculia quadrifida R. BR. which is known as faloak, belonging to the family Sterculiaceae, widely distributed in Indonesia, especially in Timor, Sumba, Alor, and Flores Island [6]. Conventionally, in Indonesia, especially East Nusa Tenggara, the bark of this plant is used to treat liver diseases, gastroenteritis and as stamina booster [7], rheumatism, and malaria [8]. The ethanolic extract of S. quadrifida bark had been reported to have cytotoxicity activity on hepatocyte cell line Huh7 and inhibition activity to HCV JFH1 replication [9], antidiabetic [10], and immunomodulatory [11]. This study aimed to study antioxidant activity of S. quadrifida bark by in vitro DPPD radical scavenging method and glutathione reductase activity in diabetic Wistar rat model.

\section{METHODS}

Chemicals

Alloxan, rutin, 1,1-diphenyl-2-picryl-hydrazyl (DPPH), and phosphate buffer were purchased from Sigma-Aldrich. GPx assay kit was purchased from BioVision. Glibenclamide was obtained from PT Indofarma. Other chemicals and reagents were of analytical grade which was used in the present evaluation.

Animal

Male Wistar rats weighed 180-200 g (age 2-3 months) were obtained from the animal laboratory of Gadjah Mada University, Yogyakarta. The rats were adapted to their environment at constant temperature of $25^{\circ} \mathrm{C}$ for a week before being used. They were given free access to feed standard pellets and water during the study. All of procedures were approved by Health Research Ethics Committee, Sebelas Maret University, with a certificate no 100/II/HREC/2017.

\section{Collection and authentication of plant material}

The bark of S quadrifida was collected from Kupang, East Nusa Tenggara, Indonesia, in Januari 2017 and authenticated from the Biology Lab, Faculty of Math and Science, Sebelas Maret University, Surakarta. Four kilograms bark of $S$. quadrifida was taken and washed properly, and then the materials were sorted while wet, dried, and grinded into powder.

\section{Extraction of plant material and phytochemical screening}

The $500 \mathrm{~g}$ dried bark powder of $S$. quadrifida was extracted by maceration using $5 \mathrm{l}$ ethanol $70 \%$ for 5 days at room temperature and protected from sunlight. After 5 days, the mixture was filtered, and the residue was washed out with ethanol and treated for 5 days as the same as treatment before. The extract was evaporated by rotary evaporator yielding $67.68 \mathrm{~g}$ of $S$. quadrifida ethanol extract. Preliminary phytochemical screening of the plant extract was performed for determining the presence of alkaloids, tannins, flavonoids, saponins, and steroid/triterpenoid. 
DPPH radical scavenging activity

The antioxidant activity of extracts was determined by DPPH assay using Blois's method [12] with minor modifications. Extract of S. quadrifida was prepared in various concentrations. $2 \mathrm{ml}$ of extract were added to $2 \mathrm{ml} \mathrm{DPPH} 80 \mu \mathrm{g} / \mathrm{ml}$ to initiate the reaction for obtaining a calibration curve. The mixture of $2 \mathrm{ml}$ DPPH solution and $2 \mathrm{ml}$ methanol was used as the control solution. The methanol was used as the blank solution and rutin as reference standard. The mixture was shaken vigorously and allowed to stand at room temperature for $30 \mathrm{~min}$ then; the absorbance was measured at $517 \mathrm{~nm}$ by ultraviolet-visible spectrophotometer. The analysis was conducted in triplicate for standard and extract. The absorbance value was assessed as the inhibitory percentage (\%). The antioxidant activity was revealed as IC $_{50}$ of DPPH scavenging activity by determining the $50 \%$ inhibitory concentration for extract using the calibration curve. The percent of DPPH scavenging activity was calculated by following equation:

Percent inhibition $=\left[A_{0}-A_{1} / A_{0}\right] \times 100$.

Where $A_{0}$ was the absorbance of control reaction and $A_{1}$ was the absorbance in presence of test or standard sample.

\section{Determination of GPx activity}

The experiment was performed for 14 days using Wistar rats. All of rats were divided into six groups comprising six rats in each group and fed the normal diet throughout the experimental period. Group I was the normal control group and received vehicle $0.5 \%$ carboxymethyl cellulose [CMC]-Na) orally. Groups II-VI were induced with alloxan monohydrate intraperitoneally to obtain diabetic with stress oxidative condition. Group II as diabetic control was orally administered vehicle. Glibenclamide was orally administered at a dose of $0.45 \mathrm{mg} / \mathrm{kg}$ bw to Group III as drug control group. Groups IV, V, and VI were orally treated with $S$. quadrifida extract in CMC-Na suspension at dose of 65,130 , and $260 \mathrm{mg} / \mathrm{kg}$ bw, respectively. Before inducing by alloxan monohydrate, the blood sample was collected for glucose level assay on $0^{\text {th }}$ day $\left(\mathrm{T}_{0}\right)$. Briefly, the rats were injected intraperitoneally with $180 \mathrm{mg} / \mathrm{kg}$ bw alloxan monohydrate (suspended in $\mathrm{NaCl} 0.9 \%$ ) to increase the glucose level, except for normal control group. After $5^{\text {th }}$ days of alloxan induction, the blood glucose level was measured. The rats with glucose level above $200 \mathrm{mg} / \mathrm{dl}$ were assigned for 14 days treatment. At the end of the experimental period ( $15^{\text {th }}$ days), the rats were starved overnight and then sacrificed, the liver was used for the measurement of GPx activity. The GPx activity assay of the extract was performed by the method of Lawrence and Burk [13] with minor modification. Briefly, $200 \mu \mathrm{l}$ of liver supernatants were added to the mixture consisting of $200 \mu \mathrm{l}$ phosphate buffers $0.1 \mathrm{mM}$ pH 7.4 (contains EDTA $0.1 \mathrm{M}$ ), $200 \mu \mathrm{l}$ glutathione (GSH) $10 \mathrm{mM}$, $200 \mu$ l glutathione reductase $2.4 \mathrm{U} / \mathrm{ml}$, and $200 \mu$ l NADPH $1.5 \mathrm{mM}$. The mixture was incubated at $37^{\circ} \mathrm{C} 10 \mathrm{~min}$ and then $200 \mu \mathrm{l} \mathrm{H} \mathrm{O}_{2} 1.5 \mathrm{mM}$ was added to above mixture. The change in absorbance of the sample was measured at $\lambda 340 \mathrm{~nm}$ using spectrophotometer for $3 \mathrm{~min}$. The GPx enzymatic activity was calculated as $\mu$ mol NADPH that oxidized to $\mathrm{NADP}^{+}$minute $^{-1} \mathrm{mg}^{-1}$ protein with extrinsic coefficient NADPH $6.22 \mathrm{mM}^{-1} \mathrm{~cm}^{-1}$, the results were expressed as units of GPx activity/mg cell protein and were calculated using equation:

$$
\mathrm{M} \text { unit GPx }=\frac{\mathrm{Abs} \times \mathrm{Vt} \times 2 \times 1000 \times 1 / \mathrm{mg} \text { protein }}{6.22 \times \mathrm{Vs}}
$$

Where Abs was the change of the absorbance; Vt was the total volume $(\mathrm{ml})$; Vs was the sample volume (ml); 2 was the equivalent of 2 mol GSH with 1 mol NADPH; 6.22 was the NADPH molar extinction coefficient (in $\mathrm{Mm} . \mathrm{cm}^{-1}$ ); and 1000 was the conversion of ml unit.

\section{Data analysis}

The results were represented as the mean \pm standard deviation. The statistical significance of difference to DPPH radical scavenging activity was calculated by t-test, and for GPx activity was calculated by Mann-Whitney test. Statistical significance was set at $\mathrm{p}<0.05$.

\section{RESULTS AND DISCUSSION}

\section{Identification of the compound of $S$. quadrifida bark extract}

Identification of the compounds using chemical reaction method showed that the ethanol extract of S. quadrifida bark contains flavonoid, triterpenoid, saponin, tannin, and alkaloid.

\section{In vitro DPPH radical scavenging activity}

The relatively stable DPPH radical had been used widely to test the ability of compounds to act as free-radical scavengers or hydrogen donors. This capability was used to evaluate antioxidant activity. Compounds with radical scavenger capacity are able to reduce DPPH radical using donor hydrogen atom to DPPH free-radical based on the type and concentration of sample. Interaction of antioxidant compound with DPPH is based on transfer electron or hydrogen atom to DPPH radical and converts it to $1 \mathrm{DPPH}$. The result of reduction DPPH radicals causes discoloration from purple color to yellow pale color which indicates the scavenging activity. The decrease of absorbance of DPPH radicals was measured by spectrophotometer. The absorbance was measured at $517 \mathrm{~nm}$ for each concentration of extract and standard. The percentage inhibition of all concentration series of extract and rutin was calculated. The value of $\mathrm{IC}_{50}$ was calculated using regression linear equation. $\mathrm{IC}_{50}$ is the ability of the compounds to inhibit $50 \%$ DPPH activity.

The $\mathrm{IC}_{50}$ value of ethanol extract of faloak bark and rutin is $4.86 \mu \mathrm{g} / \mathrm{ml}$ and $4.23 \mu \mathrm{g} / \mathrm{ml}$, respectively. The previous research by Saragih and Siswadi [14] exposed that S. quadrifida bark extracts had DPPH radical scavenging activity by $\mathrm{IC}_{50}$ of $2.51+0.03 \mu \mathrm{g} / \mathrm{ml}$. These result indicated that the extracts and standard rutin had very strong antioxidant activity. The sample had $\mathrm{IC}_{50}<50 \mathrm{ppm}$, it was very strong antioxidant, 50-100 ppm strong antioxidant, and 101-150 $\mathrm{ppm}$ medium antioxidant, while weak antioxidant with $\mathrm{IC}_{50}>150$ ppm [15].

A potential source of antioxidant agents may be derived from the natural products. Flavonoids are groups of plant polyphenols, which display antioxidant activity and varied pharmacological activities [16]. The study of ten flavonoids catechin, epicatechin, epigallocatechin, epicatechin gallate, epigallocatechin gallate, myricetin, quercetin, apigenin, kaempferol, and luteolin showed that these compounds had the radical scavenging capacity toward DPPH radical [17].

The result of statistical analysis using independent samples t-test to compare the average of $\mathrm{IC}_{50}$ rutin and extract showed that the values were significantly different $(\mathrm{p}<0.05)$. The result of antioxidant activity of $S$. quadrifida bark extract and standard rutin is shown in Table 1.

\section{In vivo antioxidant of GPx activity}

GPx is an important intracellular enzyme that breakdown hydrogen peroxides $\left(\mathrm{H}_{2} \mathrm{O}_{2}\right)$ to water and lipid peroxides to their corresponding alcohols, mainly in the mitochondria and sometimes in the cytosol. GPx plays a key role in protecting the cell from free-radical-induced damage, particularly lipid peroxidation. The enzyme also catalyzes the reduction of hydrogen peroxide and organic peroxides (ROOH) to water and corresponding stable alcohols $(\mathrm{ROH})$, respectively, using

Table 1: The $\mathrm{IC}_{50}$ value of ethanolic extract of Sterculia quadrifida bark and rutin

\begin{tabular}{llll}
\hline Solutions & Replication & $\mathbf{I C}_{50}(\mathbf{u g} / \mathbf{m l})$ & $\begin{array}{l}\text { Mean } \\
\mathbf{I C}_{50} \pm \text { SD }\end{array}$ \\
Sterculia quadrifida & 1 & 4.86 & $4.86 \pm 0.01$ \\
bark extract & 2 & 4.86 & \\
Standard rutin & 3 & 4.87 & \\
& 1 & 4.23 & $4.23 \pm 0.01$ \\
& 2 & 4.24 & \\
\hline
\end{tabular}


reduced glutathione as a source of reducing equivalents. When oxidized glutathione is produced upon reduction of organic peroxide by GPx, it was recycled to its reduced state by glutathione reductase with oxidation of NADPH to NADP+. The process of NADPH oxidation was accompanied by a decrease in absorbance at $340 \mathrm{~nm}$ for monitoring the activity of GPx.

The results of GPx activity assay from extract of S. quadrifida bark and standard rutin are shown in Table 2. The extracts treatment groups at a dose of 65,130 , and $260 \mathrm{mg} / \mathrm{kg}$ bw were significantly $(\mathrm{p}<0.05)$ increased the GPx activity in liver tissue $(36.7 \pm 0.66$; $50.87 \pm 1.90$; and $56.10 \pm 0.94 \mathrm{U} / \mathrm{mg}$ tissue, respectively) compared to the diabetic control group (25.87 $\pm 1.07 \mathrm{U} / \mathrm{mg}$ tissue). Activity of faloak extract at dose of $300 \mathrm{mg}$ was higher than two other doses. Furthermore, the GPx activity of treatment groups rat, extract, and standard glibenclamide, was significantly different compared to normal control group $(p<0.05)$, which was only received vehicle (CMC-Na). These data indicated that all of the extracts had potential activity. However, GPx increasing activity of S. quadrifida extract and standard glibenclamide has not reached the normal level.

The diabetic control group showed the lowest GPx activity value $(25.87 \pm 1.07 \mathrm{U} / \mathrm{mg})$ and significantly different compared to the normal group $(\mathrm{p}<0.05)$. The diabetic control group was only given vehicle ( $0.5 \% \mathrm{Na}$ CMC) for 14 days after have hyperglycemia conditions due to alloxan induction. Normal control and glibenclamide showed GPx activity value $77.79 \pm 3.28 \mathrm{U} / \mathrm{mg}$ and $62.83 \pm 1.44 \mathrm{U} / \mathrm{mg}$, respectively. These values were close to the value of GPx activity that has been reported [18].

Alloxan as a reactive compound, quickly to the pancreas and accelerate the formation of ROS that can cause molecular modification. This is the beginning of oxidative damage due to an imbalance between protective antioxidants and increased free-radical production. The production of free radical cannot be totally neutralized by endogenous antioxidant (GPx). The administration of S. quadrifida extract to the diabetic rats increased the activities of these enzymes almost achieved the normal level, especially at dose $260 \mathrm{mg} / \mathrm{kg}$ bw.

Phytochemical screening of $S$. quadrifida extract showed the presence of alkaloid, terpenoid/steroid, saponin, tannin, and flavonoid compounds. Flavonoids, such as quercetin and rutin, showed antioxidant effects against damage caused by excess ROS of sickle cell anemia [19]. Moreover, many studies also indicated that flavonoid compounds induced the GPx activity. Flavonoid rutin could induce glutathione and GPx activities in the testis of adult rats that were induced using cadmium [20]. The treatment with silymarin significantly lowered the level of lipid peroxidation and enhanced the antioxidant status and resulted a reduction of the necrotic damage caused by nickel and thereby restored the previous biochemical parameters [21].

The study suggested that $S$. quadrifida had been partially reduce the imbalances between the generation of ROS and the scavenging enzyme activity. According to these results, $S$. quadrifida could be used a supplement, as an antioxidant therapy, and preventing diabetic complications due to lipid peroxidation and free radicals.

Table 2: Activity of glutathione peroxidase

\begin{tabular}{ll}
\hline Groups & GPx activity $(\mathbf{U} / \mathbf{m g}) \pm$ SD \\
\hline Group I: Normal control & $77.79 \pm 3.28$ \\
Group II: Diabetic control & $25.87 \pm 1.07$ \\
Group III: Glibenclamide $0.45 \mathrm{mg} / \mathrm{kg} \mathrm{bw}$ & $62.83 \pm 1.44$ \\
Group IV : Extract $65 \mathrm{mg} / \mathrm{kg} \mathrm{bw}$ & $36.73^{\mathrm{abc}} \pm 0.66$ \\
Group V: Extract $130 \mathrm{mg} / \mathrm{kg} \mathrm{bw}$ & $50.87^{\mathrm{abc}} \pm 1.90$ \\
Group VI: Extract $260 \mathrm{mg} / \mathrm{kg} \mathrm{bw}$ & $56.10^{\mathrm{abc}} \pm 0.94$ \\
\hline
\end{tabular}

${ }^{a}$ significantly different compared to normal control $(\mathrm{p}<0.05)$, ${ }^{\mathrm{b}}$ significantly different compared to diabetic control $(p<0.05)$, ${ }^{\text {s significantly different }}$ compared to glibenclamide $(\mathrm{p}<0.05)$

\section{CONCLUSION}

The ethanol extract of $S$. quadrifida bark had very strong antioxidant activity by DPPH radical scavenging with $\mathrm{IC}_{50}$ value of $4.86 \mathrm{ug} / \mathrm{ml}$. The ethanol extract of $S$. quadrifida bark dose of $260 \mathrm{mg} / \mathrm{kg}$ bw showed the highest GPx activity in diabetic rats.

\section{ACKNOWLEDGMENT}

We sincerely acknowledge to Dr. Rina Herawati for her grammatical editorial.

\section{AUTHOURS' CONTRIBUTIONS}

The author declares that all the named authors have contributed equally to this article.

\section{CONFLICTS OF INTEREST}

All authors report no conflicts of interest regarding this manuscript.

\section{AUTHORS' FUNDING}

None.

\section{REFERENCES}

1. Tahir I, Khan MR, Shah NA, Aftab M. Evaluation of phytochemicals, antioxidant activity and amelioration of pulmonary fibrosis with Phyllanthus emblica leaves. BMC Complement Altern Med 2016;16:406.

2. Pandey N, Barve D. Antioxidant activity of ethanolic extract of Annona squamosa Linn bark. Int J Pharm Biomed Res 2011;2:1692-7.

3. Mahdi-Pour B, Jothy SL, Latha L, Chen Y, Sasidharan S. Antioxidant activity of methanol extracts of different parts of Lantana camara. Asian Pac J Trop Biomed 2012;2:960-5.

4. Ighodaro OM, Akinloye OA. First line defence antioxidants-superoxide dismutase (SOD), catalase (CAT) and glutathione peroxidase (GPX): Their fundamental role in the entire antioxidant defence grid. Alex $\mathrm{J}$ Med 2016;54:287-93.

5. Deepika S, Rajagopal SV. Evaluation of in vitro antioxidant activity of flowers of Blepharis molluginifolia. Int J Pharm Sci Res 2014;5:2225-9.

6. Siswadi S, Saragih GS. Acute tocixity of Sterculia quadrifida R.Br bark ethanol extract on Sprague dawley rats. Tradic Med J 2018;23:127-34.

7. Munawaroh R, Siswadi S, Setyowati EP, Murwanti R, Hertiani T. Correlation between total flavonoid contents and macrophage phagocytosis activity of fractions from faloak (Sterculia quadrifida R.Br.) barks ethanolic extract in vitro. Tradic Med J 2018;23:47-55.

8. Asmiati, Lestari N, Uslan. Morphological and anatomical characteristic kinship of faloak plant (Sterculia quadrifida $\mathrm{R} . \mathrm{Br}$ ) as learning source for morphology and anatomy of plant course based on local natural resources. Adv Soc Educ Nat Res 2019;355:72-5.

9. Dean M, Handajani R, Khotib J. Faloak (Sterculia quadrifida R.Br) stem bark extract inhibits hepatitis C virus JFH1. Orient J Chem 2019;35:430-5.

10. Dongga IR, Sunarti S, Sunarti T. Antidiabetic ethanol extract of faloak (Sterculia quadrifida R.Br.) barks on alloxan-induced Wistar rats. J Farm Ind 2016:8:144-9.

11. Winanta A, Hertiani $\mathrm{T}$, Purwantiningsih, Siswadi. In vivo immunomodulatory activity of faloak bark extract (Sterculia quadrifida R.Br). Pak J Biol Sci 2019;22:590-6.

12. Blois M. Antioxidant determination by the use of stable free radical. Nature 1958;181:1199-200.

13. Lawrence RA, Burk RF. Glutathione peroxidase activity in selenium deficient rat liver. Biochem Biophys Res Commun 1976;71:952-8.

14. Saragih GS, Siswadi S. Antioxidant activity of plant parts extracts from Sterculia quadrifida R.Br. Asian J Pharm Clin Res 2019;12:143-8.

15. Fidrianny RD, Rizki RR, Insanu M. In vitro antioxidant activities from various extracts of banana peels using ABTS, DPPH assays and correlation with phenolic, flavonoid, carotenoid conten. Int J Pharm Pharm Sci 2014;6:299-303.

16. Alrawaiq NS, Abdullah A. A review of flavonoid quercetin: Metabolism, bioactivity and antioxidant properties. Int J Pharmtech Res 2014;6:933-41.

17. Hirano R, Sasamoto W, Matsumoto A, Itakura H, Igarashi O, Kondo K. Antioxidant ability of various flavonoids against DPPH radicals and LDL oxidation. J Nutr Sci Vitaminol 2001;47:357-62. 
18. Widodo GP, Herowati R, Perangin-Angin JM, Kamlasi JE. Antihyperglycemic, antioxidant, and pancreas regeneration activities of black cumin (Nigella sativa L.) seeds ethanol extract in alloxan-induced diabetic rats. Int J Pharm Pharm Sci 2016;8:37-40.

19. Henneberg R, Otuki MF, Furman AE, Hermann P, Nascimento AJ, Leonart MS. Protective effect of flavonoids against reactive oxygen species production in sickle cell anemia patients treated with hydroxyurea. Rev Bras Hematol Hemoter 2013;35:52-5.
20. Abarikwu SO, Olufemi PD, Lawrence CJ, Wekere FC, Ochulor AC, Barikuma AM. Rutin, an antioxidant flavonoid, induces glutathione and glutathione peroxidase activities to protect against ethanol effects in cadmium-induced oxidative stress in the testis of adult rats. Andrologia 2017;49:e12696.

21. Bouhalit S, Kechrid Z. Protective effect of silymarin extracted from Silybum marianum seeds upon nickel-induced hepatotoxicity in Albino Wistar rats. Ann Microbiol Immunol 2018;1:1-5. 